\title{
Verb with Suffix -nya as a Definite Marker in Colloquial Jakartan Indonesian
}

\author{
$\mathrm{N} \mathrm{Gesita}^{\mathbf{1}}$, T Suhardijanto ${ }^{2}$ and Z Nuriah ${ }^{3}$ \\ \{1'gesitanorma@gmail.com, ${ }^{2}$ suhardiyanto@gmail.com, ${ }^{3}$ zahroh.nuriah@ui.ac.id\} \\ 1,2,3 Department of Linguistics, Faculty of Humanities, Universitas Indonesia
}

\begin{abstract}
Basically the definiteness are related to nouns or nominal phrase. But with dependency analysis, we can found evidence that in Colloquial Jakartan Indonesian definite meaning can be achieved not only in nouns but also by adding suffix -nya to verb. There's special characteristic of verb with suffix -nya as a definite marker. Suffix -nya as a definite marker can be attached to intransitive and transitive verb but with a different result. Suffix -nya give a definite meaning to a verb that indicated intransitive. In the other hand, suffix nya as a definite marker that attached to transitive verb didn't change that verb into definite, but changing the the object referred by that verb instead into definite. There are two function of suffix -nya that attached to transitive verb, namely as a definite marker and as an anaphoric marker. Suffix -nya as an anaphoric marker showed that the transitive verb didn't followed by object in the same sentence.
\end{abstract}

Keywords: definite marker, dependency grammar, Indonesian language, suffix - nya, verb

\section{Introduction}

Suffix -nya is one of the most frequent and polysemic suffixes in Indonesian language[1]. Its main function in formal Indonesian is generally as a third person singular pronoun. However, in spoken Indonesian there are many functions of the suffix -nya which are not available in formal Indonesian. The suffix -nya as a definite marker is a function that characterizes spoken Indonesian and is difficult to find the example in formal Indonesian. Research on suffix -nya as a definite marker has been extensively done by linguists although the term of suffix -nya as a definite marker is different in each of those studies. Kridalaksana called it a certain meaning (bermakna tentu)[2], Englebretson called it suffix -nya as an identifiability marker[3], Sneddon called it suffix -nya as a marker of definiteness and as an emphasizer[4], and Perangin-angin called it suffix -nya as a determinator like element[5]. However, even though it has a different term for suffix -nya function, basically four of them have the same definition.

The suffix -nya in Indonesian is not the only definite marker. In general, Indonesian language is one of the languages that does not have special article as definite or indefinite markers. To modify the noun phrase to have a definite meaning, it is always marked by a 
demonstrative, a possessive or some other element which identifies it. The suffix -nya is one element that can be describe as a definite marker in Indonesian[4].

This is not like the other languages which generally have a special sign of definiteness or indefiniteness. In many languages, certain rules apply that make a noun phrase either definite or indefinite. The most common rules is using lexical item like definite and indefinite articles in English (the, a), or using some kinds of affix like definite prefix al-and indefinite suffix $-n$ in Arabic. Such definite and indefinite markers refer to articles, elements used to limit or modify nouns [1]. Therefore, the suffix -nya as a definite marker in Indonesian is something that is more complex than the definite markers in English or Arabic.

Many linguists agree that basically the definiteness are related to nouns. Lyons said that there is a general principle of nouns and nominal phrase that can be regarded as definite and indefinite[6]. It is also supported by Hawkins which says that the information contained in the nouns is generally divided into two, definite and indefinite based on whether the information to be submitted is specific or generic[7]. Indefinite meaning appears when the information conveyed through the noun is generic. Meanwhile, the definite meaning that comes up with nouns indicates that the noun is meant to be specific or more conceivable by the hearer than indefinite nouns. However, in Indonesian language, the definite meaning arises because the suffix -nya as a definite marker is not confined only to the noun. In Perangin-angin's research, the suffix -nya as a definite marker or thet he called determiner like element, can be attached to verb, proper name, and interogative and change that word into definite[5]. Unfortunately, the characteristics of verbs that can be followed by a suffix -nya as a definite marker yet to be explained. Therefore, the main purpose of this study is to explain the characteristics of verbs that can be followed by the suffix -nya as a definite marker in Indonesian language.

Considering that, the most appropriate data for this research is Indonesian spoken variety. Regarding the importance of spoken language, Kridalaksana states that data for linguistics is speech. Utterance can be analyzed to obtain language facts[8]. Colloquial Jakartan Indonesian is considered as standard colloquial Indonesian language [9].

Definite meanings are always related to referent, a specific meaning that can be identified or can be imagined[6]. Kridalaksana states that referent are outside language elements referred by elements of language[10]. Hawkins concludes, what is meant by definite meaning is (1) introduces a referent to the hearer, (2) instructs the hearer to locate the referent in some shared set of objects, (3) refers to the totality of the objects or mass within this set which satisfy the referring expression[7].

Meanwhile according to Lyons there are four basic concepts that are closely related to definiteness, such as (1) familiarity, (2) identifiability, (3) uniqueness, and (4) inclusiveness[6]. Familiarity means referring to something previously known. In order for this entity to be said to be something familiar, it depends on the linguistic context available in discourse or utterance. What is meant by this linguistic context is that the entity has been mentioned before in a narrative or conversation. Next is the concept of identifiability. Something doesn't need to be familiar to be definite or certain. Sometimes, in some cases, it needs to be identified to be definite. This means that the use of certain articles directs the other person to speak to certain references by giving a sign that he is in a position to identify him. Absolute uniqueness refers to a single entity in the world or does not have another copy. For example, like the moon, sky, earth and so on which are single entities. Inclusiveness means a situation when an entity becomes part of something. If it is associated with definiteness, it can be stated that something can be definite if it is part of something else. For example, a kitchen is a part of a house or a tire is part of a bicycle. 
Hawkins argues that to know the definite meaning of a phrase, logical intuition is the most important[7]. Semantic and syntactic analysis must be carried out simultaneously to detect whether or not there is a definite meaning of a phrase. Logic plays an important role in determining the definite or indefinite meaning that can arise from certain words or phrases. This means, whether the word or phrase mentioned is something familiar, identified, unique, or related to a particular concept.

\section{Research Methodology}

This study uses a spoken corpus composed of narrative speeches transcription and Indonesian conversations by previously recorded Indonesian native speakers. Indonesian native speakers are those who have had only Indonesian language input since birth, or those who use Indonesian both at home and outside the home, and do not learn other languages until they are at that are least 10 years old. Native speakers are prioritized for people who live in areas that predominantly speak Indonesian language, such as in Jabodetabek (Jakarta, Bogor, Depok, Tangerang, and Bekasi). In addition, preference is also given to people who do not master local languages to minimize any possibility of linguistic interference. Research subjects are limited to the age 20-35 years to avoid significant variations of Indonesian spoken language.

The narrative topic is a story that is familiar to the speakers, such as folk tales, stories taken from books or films, or even personal experiences. The speakers are asked to retell the stories that they have known before using colloquial Indonesian language. Speakers were also asked to narrate as if they were telling the story to their friends, so that the recorded Indonesian language was informal, which was commonly used. Unrestricted topics aim for the speaker to spontaneously retell the story to the hearer. Meanwhile in recording conversations no specific theme is specified. In one conversation recording, native speakers were gathered as many as 2-4 people and were welcome to converse naturally. Natural and unplanned conversations can show cognition and language production[3]. This different data retrieval technique is expected to be able to contain all the functions of the suffix -nya in Indonesian, in spoken variety. From the results of the transcription of the narrative speech and conversation, the sentences are taken, in which there is a word followed by suffix -nya for analysis.

The main concept of the corpus used is based on Sinclair, which is about texts that can be concrete evidence in language analysis[11]. The first step of this study, especially in data processing, will be using corpus-based analysis. The corpus data were collected using the KWIC (Key Word in Context) method in search mode using AntConc 3.5.6.0. Case was set as search mode, because we wanted to found a bound morpheme attached to other words. The search results were filtered manually to eliminate words that contain -nya but not as a suffix, such as hanya (only), punya (have), and so on. These sentences are then separated into excel to be numbered. Sentences that contained noun phrase with suffix -nya and were likely to have definite meanings were then separated from other sentences manually based on the definitions of definiteness from Lyons[6].

This research uses quantitative and qualitative approaches. Quantitative approaches are needed when describing sentences using the UD Pipe device as a basic framework and looking at the structure of phrases attached to the suffix -nya. UD Pipe is a device that can be used to tokenize elements in sentences, decomposition of entries, and decomposition of sentences based on dependency relations and word classes[12]. Dependence of sentences based on 
dependencies is only done for sentences in which there are suffix -nya those that are suspected as a definite marker. Analysis of structures is limited to the level of phrases and clauses with suffix -nya to find specific meanings referred to. Complete sentence analysis was not carried out to prevent too broad a discussion.

The results of the analysis using the quantitative approach are then classified using a qualitative approach [13]. Careful observation of the structure and characteristics of suffix nya as a definite marker is done to describe verb that can be followed by suffix -nya as a definite marker in Colloquial Jakartan Indonesian. Categorization is done with an in-depth description of each characteristic found in the data.

\section{Result And Discussion}

Table .1: Number of times the suffix -nya appeared in the corpus data

\begin{tabular}{lcc}
\hline & Narrative & Dialog \\
\hline Token & 11223 & 12055 \\
Suffix - nya & 716 & 670 \\
Suffix - nya as a definite marker & 502 & 460 \\
Verb followed by suffix - nya as a definite marker & 21 & 57 \\
\hline
\end{tabular}

From the corpus of 23,278 tokens, 716 suffix -nya in narrative data and 670 suffix -nya in dialog data were found. There are 502 suffix -nya as a definite marker in narrative data and 460 in dialog data. That result is contrast with the appearance of a verb that followed by suffix -nya as a definite marker in the data. Verbs followed by suffix -nya as a definite marker were found more in dialogue data than narrative data. This indicates that Indonesian native speakers are more likely to use verbs that have definite meaning using suffix -nya when speaking with someone rather than when they are monologue.

The searching for suffix -nya based on the concept of definiteness by Lyons inherent in verbs found only two types, namely based on the concepts of familiarity and inclusiveness. The suffix -nya as a definite marker never appears with the concept of uniqueness because that concept does not apply in Indonesian. This can be explained with the following example:

(9) Bulan mengelilingi Bumi.

"The moon surrounds the earth."

(10) Hari ini bulannya indah.

"The moon today is beautiful."

In english, bulan (the moon) in sentences (9) and (10) have the concept of uniqueness and considered have definite meaning because of that. Meanwhile in Indonesian language, the word bulan in sentence (9) does not considered have definite meaning, but the word bulan in setence (10) considered definite based on the concept of identification. The suffix -nya as a definite marker that attached to verb that based on the concept of identification is also nowhere to be found. It is because the concept of identification means something that can be identified or easily understood by the hearer using senses. Therefore, suffix -nya as a definite marker based on concept of identification is only can be found if it is attached to noun.

After seeing the data, I argue that verbs with suffix -nya as a definite marker cannot all be identified by the four concepts of definiteness by Lyons. Many examples of verbs with suffix - 
nya that suspected to have a definite meaning are not included in the four concepts of definiteness by Lyons.

\author{
(11) Dia mah tidurnya itu loh. \\ He/She interJeCtion sleep-NYA that inTERJECTION \\ "The slept of her is (something)."
}

The sentence above appears in the dialogue data when someone is setting weekly targets that are difficult to achieve. She said that the target was difficult to achieve because of her many activities. However, his friend refuses the fact by saying sentence (11) which means that his friend has difficulty reaching his weekly target because she uses her time more to sleep than doing something useful. The word tidur (sleep) is absolutely have a specific meaning, and made that word have a certain meaning, and exactly same according to the concept of definiteness by Hawkins and Kridalaksana. However, the word tidurnya cannot be included in the four concept od definiteness of Lyons because it was never mentioned before and does not relate to the context in the dialogue.Many occurring of verbs followed by suffix -nya that similar to sentences (11) indicates that the concept of definiteness of the noun and the verb cannot be equated. Different from nouns, verbs with suffix -nya as a definite marker can emerge immediately, without any connection to the context in the topic and also not something that can be directly identified with the five senses.

\title{
3.1 Intransitive verb
}

Kridalaksana divides Indonesian verbs into two categories based on the number of nouns accompanying them, namely intransitive verbs and transitive verbs[8]. Intransitive verbs are verbs that avoid objects, while transitive verbs are verbs that can have or must accompany an object. Verb followed by suffix -nya as a definite marker that can be found in the corpus data is 56 words.

(12) Dia mainnya nggak ama kita.

3SG playing-NYA not with $1 \mathrm{PL}$

"She is not playing with us"

(13) Jajannya banyak dia.

buying.snacks-NYA many 3SG

"She is buying snacks a lot."

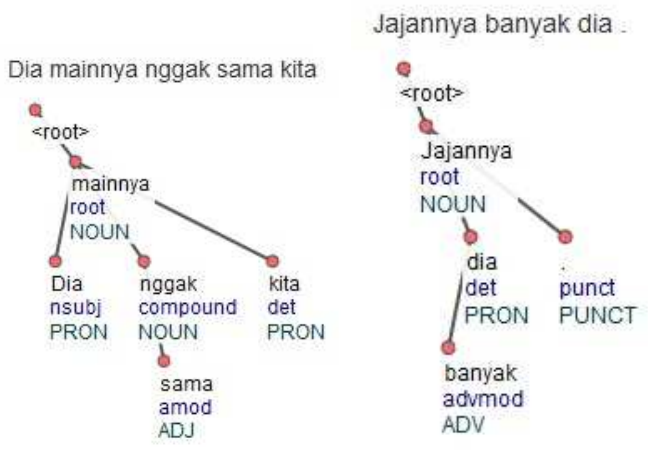

Fig 1: Decomposed sentence (12) and (13) using UD Pipe 
The decomposition of sentences using UD Pipe shows that intransitive verbs followed by suffix -nya as a definite marker generally become root in the dependency relation and are identified as noun. This shows that the intransitive verb followed by suffix -nya as a definite marker has a character that similar to a noun. Even so, the verb that followed by suffix -nya cannot be called a noun. By using a simple substitution based on the relation of paradigmatic meaning by Saussure this can be proven.

*(12a) Dia kelompok nggak ama kita.

*(12b) Dia pelajar nggak ama kita.

The two example sentences above show that the word mainnya cannot be replaced by a noun. Therefore, it is clear that the word mainnya is not a noun even though it has characters like nouns.

\subsection{Transitive verb with non-existed object}

The suffix -nya as a definite marker can also be attached to the transitive verb even though it does not appear as much as the intransitive verb. From the combination of narrative and dialogue data, only 14 transitive verbs were found that could followed by suffix -nya as a definite marker.

(14) Ngirimnya ke siapa? send-NYA to who "who sould I send it to?"

(15) Itu ngejarnya susah emang. that chase-NYA difficult really "That is really difficult to achieved."

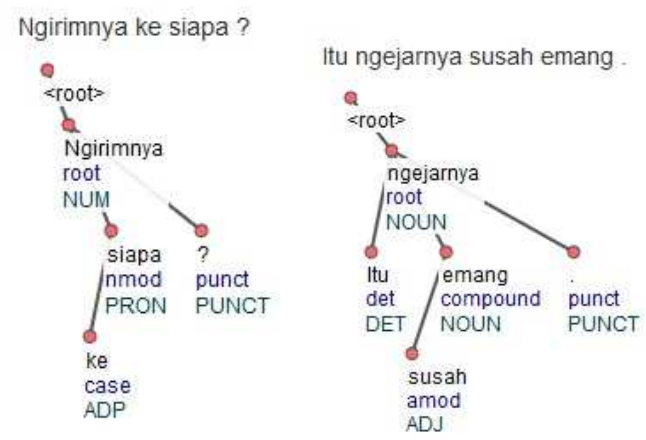

Fig 4.2: Decomposed sentence (14) and (15) using UD Pipe

Verbs followed by suffix -nya in sentences (14) and (15) looks like it is have the same characters as intransitive verbs. But, the word ngirim (informal form from mengirim) and ngejar (informal form from mengejar) are actually referred to some object based on context discussed. I argue that suffix -nya that attached to the verb in sentence (14) and (15) not only have a fuction as a definite marker but also as an anaphoric marker, because it can referred some entity on the previous sentence usually called an antecedent. Suffix -nya that attached to the word ngirim can be translated as a novel writing which became the context of discussion 
for sentence (14). Meanwhile, the suffix -nya attached to the word ngejar can be translated or referred to weekly target which became the context of discussion for sentence (15).

*(14a) Ngirim tulisan novel ke siapa?

*(15a) Itu ngejar target mingguan susah emang.

(14b) Ngirim tulisan novelnya ke siapa?

(15b) Itu ngejar target mingguannya susah emang.

Sentences (14a) and (15a) indicate that the suffix -nya is not only an anaphoric marker for the words ngirim and ngejar, because the sentence is unfinished. If we look at sentences (14b) and (15b), it becomes clear that the suffix -nya is an anaphoric marker for ngirim and ngejar, but at the same time become a marker of definiteness for objects that should accompany these two words, but are not exist.

In Perangin-angin's research it has been proven that the suffix -nya as a definite marker can be attached to the verb. Nevertheless, that research does not explain the characteristics of that verb. Seeing the results of this research, verbs that can be followed by the suffix -nya as a definite marker can be explained by their characteristics.

\section{Conclusion}

This research shows that verbs that can be followed by suffix -nya as a definite marker are intransitive verbs. In addition, intransitive verbs that have definite meanings can also be said to have characters that are similar to nouns. However, intransitive verbs followed by suffix nya as a definite marker are not nouns, so the theory which says that the suffix -nya attached to verbs are nominalizer need to be reexamined. The transitive verb can also be followed by suffix -nya as a definite marker, but it is not that verb that given the definite meaning, but the noun that should be the object of the verb. The definitions of nouns and verbs that have definite meanings is have the different concept, so further research is needed on the definition of definiteness in Indonesian language in each word class.

\section{References}

[1] P. Grangé, “The Indonesian verbal suffix -nya. Nominalization or subordination?," Wacana, vol. 16, no. 1, pp. 133-166, 2015.

[2] H. Kridalaksana, "NYA Sebagai Penanda Anafora," Beberapa Masal. Linguist. Indones., pp. 95-110, 1987.

[3] R. Englebretson, Searching for Structure: The Problem of Complementation in Colloquial Indonesian Conversation, vol. 13. Amsterdam: John Benjamins, 2003.

[4] J. N. Sneddon, Indonesian: A Comprehensive Grammar. New York: Routledge, 1996.

[5] D. M. Perangin-angin, "The Syntax of Bahasa Indonesia Enclitic - NYA," no. August, pp. 1-70, 2006.

[6] C. Lyons, Definitness. Cambridge: Cambridge University Press, 2003.

[7] J. A. Hawkins, Definiteness and Indefiniteness: A Study in Reference and Grammaticality Prediction. New York: Routledge, 2015.

[8] H. Kridalaksana, Struktur, Kategori, dan Fungsi dalam Teori Sintaksis. Jakarta: Atma Jaya, 2002 .

[9] J. N. Sneddon, Colloquial Jakartan Indonesian. Canberra: Pacific Linguistics, 2006. 
[10] H. Kridalaksana, Kamus Linguistik. Jakarta: Gramedia Pustaka Utama, 2009.

[11] J. Sinclair, Trust the Text. London: Routledge, 2004.

[12] M. Straka and J. Straková, "Tokenizing, POS Tagging, Lemmatizing and Parsing UD 2.0 with UDPipe," vol. 2, pp. 88-99, 2017.

[13] K. Saddhono, "Language and superdiversity: Indonesians knowledging at home and abroad. By Zane Goebel." Soc. Stu. vol. 12 no.1 pp. 113-118, 2018 